\title{
Women's Support in Resilience of Online Taxi Drivers' Families in Jakarta During COVID-19 Pandemic
}

\author{
Dhita Ayu Pradnyapasa'; Renny Nurhasana ${ }^{2 *}$; Ni Made Shellasih ${ }^{3}$; \\ Anita Siti Fatonah ${ }^{4}$; Fadhilah Rizky Ningtyas ${ }^{5}$ \\ 1,2Urban Studies Program, School of Strategic and Global Studies, Universitas Indonesia \\ Jl. Salemba Raya No. 4, Kenari, Senen, Jakarta Pusat 10430, Indonesia \\ ${ }^{3,4,5}$ Center for Social Security Studies, School of Strategic and Global Studies, Universitas Indonesia \\ J1. Pegangsaan Timur No. 16, Pegangsaan, Menteng, Jakarta Pusat 10320, Indonesia \\ 1dheita.ayu@gmail.com; ${ }^{2}$ renny.nurhasana@yahoo.com; ${ }^{3}$ nmshellasih@gmail.com; \\ 4anitafatonah2@gmail.com; ${ }^{5}$ fadhilahrzkn@gmail.com
}

Received: $31^{\text {st }}$ January $2021 /$ Revised: $11^{\text {th }}$ April 2021/ Accepted: $12^{\text {th }}$ April 2021

\begin{abstract}
How to Cite: Pradnyapasa, D. A., Nurhasana, R., Shellasih, N. M., Fatonah, A. S., \& Ningtyas, F. R. (2021). Women's support in resilience of online taxi drivers' families in Jakarta during COVID-19 pandemic. The Winners, 22(2), 147-153. https://doi.org/10.21512/tw.v22i2.7025
\end{abstract}

\begin{abstract}
The research aimed to assess women's support to maintain the resilience of online taxi drivers' families in Jakarta during COVID-19 pandemic. The research applied a qualitative method. Data were collected by conducting interview with four participants, who were the wives of online taxibike drivers. Four dimensions were believed to be important for family resilience within the pandemic, namely women's support to integrity variable, physical endurance, economic resilience, and socialpsychological resilience. The research finds various important women's support in maintaining the family resilience during COVID-19 pandemic. It is found that women as wives are able to retain good communication between family members, provide nutritious food for family members, support economic resilience by minimizing expenditures, manage to teach children at home while taking care of younger babies, and so forth. The research limitation is on the variability of the participants. It is suggested that further research implements quantitative methods to gain more data and expand the number of participants for more exploration.
\end{abstract}

Keywords: women support, family resilience, online taxi drivers

\section{INTRODUCTION}

COVID-19 is an infectious disease caused by a new virus derived from the coronavirus type which is referred to as Severe Acute Respiratory Syndrome Coronavirus 2 (SARS-CoV-2). This is a new virus which is a similar type of virus that caused an outbreak in 2002 ("Transmission of SARS-CoV-2", 2020). Based on data as of October 3, 2020, there were 299.506 COVID-19 cases recorded in Indonesia, with the metropolis as the largest contributor to the number of cases. DKI Jakarta as the center of the capital is severely infected as data shows one million positive cases in January 2021. The dense capital city area is one of the catalysts in the spread of this virus transmission, which causes national health crisis.

As a result of intense widespread, the government took several efforts to suppress the spread of this virus. One of the efforts was to implement Pembatasan Sosial Berskala Besar/PSBB (LargeScale Social Restrictions) to restrict the physical contact of the community. DKI Jakarta is one of the regions that has implemented the first phase of PSBB, commencing from April 10 to June 4, 2020. This has been regulated in the Special Regulation of the Governor of DKI Jakarta No. 33/2020 concerning the implementation of PSBB. This social restriction has a social and economic impact on various fields in society as it limits people for work (Iswari et al., 2020). One of the affected work fields is public transportation.

One of the public transportations that has been impacted is 'Online Taxi'. Online taxi is an informal sector currently and widely used in Indonesia, and is continuously growing (Suprayogaswara, 2017). Based on the DKI Jakarta Governor Regulation No. $33 / 2020$, the PSBB period had caused the online taxibike drivers restricted to only transporting goods, not passengers. The number of passengers for online taxi-car were limited. According to Eddy and Harahap (2020), it is known that the proportion of online taxibike drivers' income decreased by around 58,14\%. This affects the family income (Lizya et al., 2021). 
In 2020, it was stated that there was a significant decrease in income during the PSBB period, while drivers still had to compete with other drivers for passengers. This income reduction can indirectly affect the resilience of online taxi drivers' families.

Indicating from the perspective of National Resilience, family resilience is one of the most important frontline vanguards to maintain and strengthen the nation. This is due to the important role of family resilience in realizing quality human resources (Puspitawati \& Herawati, 2018). Family resilience can be defined as a condition that a family has in the form of tenacity and toughness containing physical and material abilities that are useful for sustaining and developing themselves, creating a harmonious family and improving physical and mental welfare and happiness (Decree No. 52, 2009). Many shall play a role in maintaining family resilience, one of which is the support of women in the family.

The support of women in family resilience is crucial due to the responsibility of a woman's substantial roles in each household activity (Robinson \& Bessell, 2002). Assessing family resilience uses the concept of Family Resilience and Welfare issued by the Ministry of Women Empowerment and Child Protection (MoWECP) No. 6 of 2013 concerning the implementation of Family Development. The assessment is done through five-dimension-assessment with 15 variables.

The importance of women's support in family resilience have been variously studied. However, the specific study related to the women's support in online taxi's families are rarely discussed. The research objective is to assess women's support to maintain the resilience of online taxi driver's families in Jakarta during COVID-19 pandemic using qualitative data collection method. It is important to discuss the issue since the number of online taxis in Jakarta are growing.

\section{METHODS}

The research applies a descriptive research design with a qualitative approach. Qualitative research emphasizes research procedures that will produce data in the form of words which describe the behavior or events of the object being observed. This method is used to explore and describe the wife's support for family resilience using words so that it could be seen comprehensively the problems experienced by online taxi drivers' wives during the COVID-19 pandemic.

The research location is conducted in the DKI Jakarta area since it is one of the provinces with high increase of COVID-19 cases in Indonesia. The sampling technique is purposive sampling to represent the number of participants required. The method is indepth interview which is conducted by using a zoom meeting application so that a two-way communication occurs. The participants are the wives of online taxi drivers who previously participate in the Focus Group Discussion (FGD) prior to the COVID-19 pandemic, which is held with several online taxi drivers to find out how much their income increased before and after becoming online taxi drivers. In the research, four wives of online taxi drivers are interviewed.

Before starting the interview, the research objectives and terms for voluntary participation are explained to the participants. Research participants have signed the consent form digitally and the confidentiality of the identities of study participants is guaranteed. The participant's identity is erased in the transcript, so initials are used to label the transcript. All interview processes are recorded via video and audio with the permission of the research participants, which can be accessed only by the researcher for research purposes. The interview was conducted from 8 August 2020 to 11 August 2020.

The interview instrument refers to the indicators of family resilience issued by the Ministry of Women Empowerment and Child Protection (MoWECP) Republic of Indonesia. The research instrument is modified by following the research objectives. The data analysis is performed using the content analysis of the interview transcript. This analysis systematically converts several texts into a highly ordered and concise summary of the main results (Erlingsson \& Brysiewicz, 2017). In order to maintain the accuracy of the information, data collection is carried out on the same day as the data analysis. Audio recording for the transcript is administered in less than 24 hours after the interview was conducted.

\section{RESULTS AND DISCUSSIONS}

There are four online taxi drivers' wives, whose husbands are still working during the COVID-19 Pandemic. The age of the participants ranges from 21 to 32 years. All respondents have two children whose ages range from 9 months to 10 years (Table 1). Information also explores on the side job that a wife may increase family income.

Driver 1's wife (D1) is 30 years old having two children. Her first child is nine years old and the second child is seven years old. Driver 2's wife (D2) is 32 years old with two children. Her first and second child is ten and six years old respectively. Driver 3's wife (D3) is 28 years old having two children as well. The oldest child is seven years old and the youngest is nine months old. Overall, the data shows that D1, $\mathrm{D} 2$, and D3 do not have side jobs thus there is no other source of income for the family. Meanwhile, Driver 4's wife (D4), a 21-years-old mother of two children (five and three years old), sells clothes online as her side job.

Dimension one is online taxi drivers' wives' support for the family integrity. It has three variables and seven indicators. In the research, two variables are assessed, namely family integrity and gender partnership. In the family integrity variable, one variable will be assessed. The indicator of this variable is that all family members, whether husband, wife 
Table 1 Informant's Descriptive Data

\begin{tabular}{|c|c|c|c|c|}
\hline No & Informant & Age (years) & Children (years old) & Side Job/Income \\
\hline 1. & Driver's Wife 1 (D1) & 30 & $\begin{array}{l}1^{\text {st. }}: 9 \\
2^{\text {nd: }}: 7\end{array}$ & Not available \\
\hline 2. & Driver's Wife 2 (D2) & 32 & $\begin{array}{l}1^{\text {st }}: 10 \\
2^{\text {nd: }}: 6\end{array}$ & Not available \\
\hline 3. & Driver's Wife 3 (D3) & 28 & $\begin{array}{c}1^{\text {st }}: 7 \\
2^{\text {nd }}: 9 \\
\text { months }\end{array}$ & Not available \\
\hline 4. & Driver's Wife 4 (D4) & 21 & $\begin{array}{l}1^{\text {st: }}: 5 \\
2^{\text {nd. }}: 3\end{array}$ & Online Clothing/up to IDR 500.000 (USD 34,5) \\
\hline Tota & & 4 Participants & & \\
\hline
\end{tabular}

with or without children, live in one house and none are separated. Based on interviews with four drivers' wives, three of them live with their husbands while one lives separately from her husband.

"Yes, I live far away from my husband, I am in Cianjur, my husband works as a driver in Jakarta, " said by D3.

Another online taxi driver's wife said that the reason for staying with their husband is because they think about their children's condition.

\section{“...I still survive because of my children.. " noticed by} D4.

Further questions explore how the wives support their husbands to make a living during this pandemic. Two respondents state that husband and wife always provide support in the form of motivation to deal with the era of COVID-19 pandemic.

"I continuously support him to maintain his motivation to meet our daily needs. I always remind him to keep praying, look after his own health and his daily meals when he goes to work every day", said by D1.

"Whatever is happening right now has become our life test. Not only did I strengthen my husband, but my husband also gave me the motivation that there will be times we are happy again", said by D2.

Online taxi-bike drivers' wife who does not live in the same house with her husband still provides support by maintaining communication and paying attention to her husband so that he is always safe at work.

"My support during this pandemic, I always remind my husband to stay healthy and comply with health protocols. We are never late to communicate every day", said by D3.

The next variable is gender partnerships which have four indicators. Any indicator assessed is openness in financial management. This indicator assesses whether the husband and wife can jointly manage family finances transparently. Most of the drivers' wives admit that they are being transparent with their husbands in managing the family finances. They acknowledge that it is difficult to manage family finances, especially when the husbands' income decrease as an impact of the PSBB policy. One of the wives states that in meeting daily needs during the pandemic, she asks parents for help.

Dimension two is support of the drivers' wives for physical endurance. The dimensions of physical endurance have one variable which is the adequacy of food and nutrition. Food adequacy is seen based on the ability of family members to fulfil two complete meals per day. The complete food category includes rice, vegetables, fish, tempeh, tofu, and fruit. Based on the results of interviews, a decrease in income due to PSBB made them minimize their family's needs, one of which was food. The majority of drivers' wives still rely on their husbands to meet the food needs of their families. However, the wives still prioritize providing nutritious food for their family members, especially their children.

"PSBB caused our income to decrease. All needs are minimized .. ", noticed D1.

"I prioritize nutritious ones because my children are still young, they still need good nutrition. I try to give priority to food needs, " said D3.

Even though the husbands' income has decreased, some of the wives are making efforts to meet family needs. A few become online sellers for clothes as a side job, and some empower the house yard to be a planting medium as a source of family food.

"Incidentally there is a house yard that can be benefitted from," said D1.

The aid from the government or the private sector is also crucially helpful in fulfilling family meals. They claim to get social aid from the government in the form of rice, instant noodles, canned fish food, sugar, flour, cooking oil, and vitamin C. The wives take advantage of this assistance to supplement their family consumption in this pandemic. Besides, there is also private aid where the husbands sometimes get 
rice box which is then brought home to their family.

The next indicator is the nutrition adequacy. It is judged by whether family members suffer from nutritional problems. Nutritional problems in question are extremely thin, fat, and stunted. The wives point out that no one is diagnosed with nutritional problems. However, the wives are worried about the fulfillment of their children's nutrition, considering that the majority of the participants' children are still growing. They always think positively and strive for the fulfillment of the nutritional needs of their children.

"Thank God we are all here in good health. No one is malnourished. For food, I prioritize nutritious ones because my children are still young, they still need good nutrition. I try to prioritize food needs", said D3.

Dimension three is support from the wives of online taxi drivers to economic resilience. In this dimension, economic resilience is assessed based on four variables with seven indicators. The first variable is a family residence with homeownership indicator. Three of the four participants do not have their own homes. Only one informant owns a house, which is located in her hometown, not Jakarta. The rest of the participants rent houses. Participants admit that they had been unable to pay for rent during this pandemic. Furthermore, they try to help their husbands, one of which is by borrowing from their families. Some ask for relief in the form of instalments or delaying payments to the homeowner.

"Yes, my husband and I were in arrears for rent. Then, we have to borrow it from our relatives first. Fortunately, some have it so they can cover the arrears first so that we are not expelled," said D1.

"In arrears at some times, but my husband and I try to talk nicely to the owner when things are difficult. Luckily the owner is a nice person, so we can postpone the payment. The important thing is we will pay," noticed D2.

The next variable is family income, which is assessed based on the per capita income of the online taxi drivers' family during the pandemic. Three wives admit that their husbands' incomes have dropped dramatically. They do not have side jobs, so they rely on income from their husbands. Meanwhile, their husbands' main income is only from online taxi driver. To meet family needs, one of the wives sell clothes online. However, it is rare for people to buy clothes during the pandemic. The average income earned from selling online is IDR 300.000-500.000 (USD 20,7-34,5). Other participants had tried to register for the pre-employment program held by the government, which later can be used to increase their capacity and open a business by relying on the incentive money. However, until the time the interview is conducted, there has been no result of the pre-employment card registration.
Family income can also be described by the indicator of sufficiency. This indicator is assessed by finding out whether a person has ever been in arrears of paying for electricity. The results of the interview show that some respondents are in arrears to pay electricity for up to two months. However, during the pandemic, there was a government policy which eliminates electricity bill for those with 400 watts of power.

"At that time, I was two months in arrears for electricity, fortunately, I got a decent online order of clothes. Thank God it paid off," said by D4.

The next variable is children's education tuition. This variable is measured by two indicators. The first indicator is the ability to fulfill children's education, which is measured by whether they have ever been in arrears to pay school tuition as well as school supplies. The second indicator is the sustainability of children's education assessed by children who have dropped out of school. During the pandemic, schools are closed, and school fees are already at no cost. However, during the teaching at home, parents must provide internet quota for online learning. The support of wives in their children's education during pandemic is more dominant in teaching their children compared to husbands, so wives have an important role in this. While their husbands work, they take care of household affairs, including their children's education. However, one of the wives admitted that it is a hassle to help teaching children for school since they also have babies to look after.

The last variable is family financial security assessed using two indicators. The first indicator is family savings which are seen based on ownership of savings in the form of money. Some participants have family savings that are managed by them. Although they admit that there is no money to save during the pandemic.

"During the PSBB period we can not save money, we only skimp our budget. We prioritize what is more important. I take part in managing savings because savings are for the benefit of my family as well," said D3.

The next indicator is the ownership of health insurance or other insurance in the family members. Some of the participants admit that they do not have health insurance since they are unable to pay for BPJS. However, participants always support their husbands to apply health protocols while working.

"I am being strict with my husband. I must apply the health protocol. If he just goes back home, he directly has to take a shower and changes the clothes, so that those who are at home are not infected," said D2.

Dimension four is support of the wives for social-psychological resilience. Social psychological 
resilience is assessed based on family harmony variables. It indicates on non-violent attitudes towards women by looking at the violence perpetrated between husband and wife. The wives admit that during the pandemic, their family never experienced domestic violence from their husbands. The wives must be able to control emotions and understand their husbands as a form support to maintain family harmony.

"I never received any violence. Just an ordinary argument. I have to give in when my husband gets emotional," said D4.

Family harmony can also be determined from the indicator of anti-violence behavior against children. This indicator is assessed based on the presence of violence perpetrated by parents and children. The majority of the wives are the most responsible for taking care of their children at home. During the learning from home, they admit that they never commit any violence to their children. As a mother, they admit to hold back their emotions even though the situation at home is sometimes not conducive, which makes them quite overwhelmed to manage it. However, their children have never been abused.

The COVID-19 pandemic has made various aspects of social and economic conditions even more arduous. Women's support in maintaining family integrity and harmony in the pandemic is highly influential. Family resilience is measured based on the presence of husband and wife in one house. The research has one participant who lives separately from her husband. Families who are not complete in one house have the potential to have lower family resilience. One of the characteristics of the family disintegrated where the husband and wife are not in the same house is the childcare pattern. This also affects the psychological condition of all family members (Saefullah, Giyarsih, \& Setiyawati, 2018). The wife who does not live with her husband point out that intense communication is the key to maintain the integrity of their families.

However, long-distance communication using telephone media can be one of the obstacles in the communication process. Some minor conflicts in the family may arise due to the COVID-19 pandemic. Therefore, the quality of communication between partners is needed, both verbal and nonverbal, to resolve the conflict (Pangaribuan, 2016). Al Amin (2018) also states that communication procedures are significantly urgent for the family's survival and resilience.

Gender partnerships can also be seen in the management of family savings. Gender partnerships have an equal and fair function between husband and wife in the distribution of work and roles (Puspitawati, Simanjuntak, \& Hayati, 2012). The participants admit that financial management, especially savings finance, is carried out jointly. Open financial management between husband and wife also needs to be done so that suspicion does not arise. Ownership of savings is an indicator of family economic resilience. This family's economic resilience will affect psychological and social resilience (Alie \& Elanda, 2019).

In maintaining good family resilience, adequate food and nutrition are important for all family members. During the pandemic, the wife's support in selecting and processing nutritious food is needed, even in difficult circumstances. Participants admit that they are concerned with the nutritional needs of the family since their children are in their infancy. In addition, they point out that the provision of food subsidy is profoundly helpful in fulfilling the nutritional needs of the family during the pandemic. The fulfillment of individual nutrition has a crucial role in maintaining immunity so that the body remains healthy and reduces the risk of contracting the virus. Therefore, mothers' role is essential in the keeping of family members (Valentino et al., 2020).

The level of economic welfare in the family can be described by the family's ability to meet the basic needs. Families that have been able to meet one of their primary needs, namely a house, have the potential to build a family with a better level of resilience. However, the fact shows that three out of four wives do not own a house and rent, instead. Besides, one of them starts an online shop business to support the family income. It shows that women play a role in guiding, educating children, and accompanying husbands, which affects family economic resilience (Aziz \& Sholikha, 2018).

Regarding family resilience, family income emphasizes the adequacy of meeting the needs of the family. Families who have sufficient income are believed to meet daily needs and expected to have better economic resilience than others. Income has been greatly reduced during the COVID-19 pandemic. However, the wives state that they make efforts to borrow and ask for remission from relatives due to a difficult time. Social support from relatives and people really helps ease the burden. The social support can reduce the possibility of psychological pressure on a person (Serafini et al., 2020).

Furthermore, the government is implementing distance learning in PSBB period. Parents' support in the learning process plays a critical role. The role of parents is much needed as substitute teachers at home in guiding children during the distance learning process (Cahyati \& Kusumah, 2020). Several participants admit that they are mothers who assist children in learning. Parental motivation is important in the learning that is being carried out by the child. Motivation is what will encourage children to learn (Wahidin, 2019).

A family is believed to have good psychological resistance when they can cope with various nonphysical problems such as positively controlling emotion, growing a sense of concern for their wives, and establishing a positive self-concept and a desire for family harmony (Puspitawati, 2015). Controlling emotions is one of the ways that the participants never receive domestic violence from her husband despite 
the increasing cases of domestic violence in the COVID-19 pandemic, either by husbands or by wives (Kuswanti et al., 2020).

COVID-19 pandemic has caused stress to married couples in Indonesia. Most of them are trying to retain marriage by maintaining family harmony, such as: 1) supporting each other through difficulties; 2) resolving economic crises together; 3 ) giving in to each other to avoid fighting; 4) accepting family conditions as they are; 5) remind each other to think and behave positively; 6) strengthen each other in terms of religiosity; and 7) maintaining communication between family members (Winurini, 2020). The role of women as mothers is important in paying attention to the psychological growth and development of each member of the family. Mothers as mental and emotional protectors are ready to listen to the life stories of each family member and provide positive input with support and advice (Zahrok \& Suarmini, 2018).

Family resilience is the family's ability to manage the resources owned by the family and overcome the problems to meet the physical and psycho-social needs of the family. The optimal family resilience effort can ensure the family's survival in adapting and surviving the various problems and difficulties (Musfiroh et al., 2019).

The research shows similar results with previous studies related to women's support on family's resilience. A husband plays important roles on gender partnerships to finish the family work and roles (Puspitawati et al., 2012). However, besides husband, women's role especially mothers are very important in keeping the stability of family members (Valentino et al., 2020), family economic resilience (Aziz \& Sholikha, 2018), and psychological and social resilience (Alie \& Elanda, 2019).

\section{CONCLUSIONS}

The consequences of the COVID-19 pandemic have had an impact on all aspects, both social and economic, especially on online taxi drivers. There are several dimensions of the family resilience of online taxi drivers that are greatly affected by various aspects, both economic and physical resilience. One of them is helping the family economy by opening their own business. The wife also plays a role in providing solutions to the family economic problems. Meanwhile, in the aspect of family inheritance from the family integrity dimension and the socioeconomic dimension, it is not unduly affected due to the high support from the wives. Even in uncertain circumstances, the wives always prioritize nutritional intake for their families.

Research findings show that women's support in maintaining the resilience of online taxi drivers' families during COVID-19 pandemic is important. The first dimension is family integrity variable. The wives have tried to provide support by maintaining communication and paying attention to the husbands, so they are always safe at work.

The second dimension is physical endurance. Wife have tried to afford to the adequacy of food and nutrition. Even though the husband's income has decreased, some of the wives are making efforts to meet family needs.

In the third dimension, the wives provide support to economic resilience by minimizing the expenditures and/or by borrowing from their families. Some ask for remission for rent payments to the homeowner.

The fourth dimension is wife's support for social-psychological resilience. Most of the wives are the most responsible for taking care of their children at home. During the learning from home, the participants admit that they never commit any violence to their children. As a mother, they hold back their emotions even though sometimes they are quite overwhelmed to manage situations at home. However, their children have never been abused.

The research implication shows the importance of women's support on family's resilience of online taxi families in Jakarta. The role of women is as important as the role of the husbands. Women's role especially mothers are very important in the keeping the stability of family members especially four dimensions studied in the research namely: 1) family integrity; 2) physical endurance; 3) economic resilience; and 4) social-psychological resilience. The limitation of the research is the variability of participants. It is suggested that further research implement quantitative methods to collect more data and expand the number of participants for more reliable research results.

\section{REFERENCES}

Al Amin, M. N. K. (2018). Communication as an effort to build family resilience in the study of "Ethical Value Theory." Al-Ahwal: Jurnal Hukum Keluarga Islam, 11(1), 79-90. https://doi.org/10.14421/ ahwal.2018.11107.

Alie, A. \& Elanda, Y. (2019). Perempuan dan ketahanan ekonomi keluarga (studi di Kampung Kue Rungkut Surabaya). Journal of Urban Sociology, 2(2), 31-42. http://dx.doi.org/10.30742/jus.v2i2.995.

Aziz, F. A. \& Sholikha, A. F. (2018). Pengaruh wanita dalam ketahanan ekonomi keluarga (studi kasus pada wanita pengrajin tikar pandan di Desa Pesahangan Cimanggu Cilacap. Yin Yang, 13(1), 1-13. https:// doi.org/10.24090/jpa.v18i2.2017.pp241-256.

Cahyati, N. \& Kusumah, R. (2020). Peran orang tua dalam menerapkan pembelajaran di rumah saat pandemi COVID-19. Jurnal Golden Age, 4(1), 152-159. https://doi.org/10.29408/goldenage.v4i01.2203.

Decree No. 52 (2009). Population Development and Family Development. Republic of Indonesia (pp. 1-44).

Eddy \& Harahap, U. N. (2020). Pemberlakuan Work From Home (WFH) dan dampak ekonominya bagi pengemudi ojek online. Jurnal Simetri Rekayasa, 2(1), 66-71. http://jurnal.harapan.ac.id/index.php/ 
JSR.

Erlingsson, C. \& Brysiewicz, P. (2017). A hands-on guide to doing content analysis. African Journal of Emergency Medicine, 7(3), 93-99. https://doi. org/10.1016/j.afjem.2017.08.001.

Iswari, I., Saragi, R. A., Sirait, R. R., \& Putra, W. (2020). Analisis perbedaan pendapatan driver Go-Jek sebelum dan saat terjadi pandemi COVID-19 di Kota Medan. Al-Sharf: Jurnal Ekonomi Islam, 1(1), 94-102. https://doi.org/10.30596/al-sharf.v.

Kuswanti, A., Muqsith, M. A., Zainal, A. G., \& Oktarina, S. (2020). Manajemen komunikasi keluarga saat pandemi COVID-19. SALAM: Jurnal Sosial dan Budaya Syar-I, 7(8), 707-722. https://doi. org/10.15408/sjsbs.v7i8.15959.

Lizya, S., Ningtyas, F. R., Shellasih, N. M., \& Nurhasana, R. (2021). The impact of COVID-19 on sociopsychological and cultural conditions of online taxi drivers in achieving sustainable city. IOP Conf. Ser.: Earth Environ. Sci., 716(1), 012061.

MoWECP Regulation No. 6 (2013). Family Development Implementation. Republic of Indonesia.

Musfiroh, M., Mulyani, S., Budi, E., Nugraheni, A., \& Sumiyarsi, I. (2019). Analisis faktor-faktor ketahanan keluarga di Kampung KB RW 18, Kadipiro Village, Surakarta City. Placentum, 7(2), 61-66.

Pangaribuan, L. (2016). Kualitas komunikasi pasangan suami istri dalam menjaga keharmonisan perkawinan. Jurnal Simbolika, 2(1). http://ojs.uma. ac.id/index.php/simbolika/article/view/214/163

Puspitawati, H. (2015). Kajian Akademik: Kebijakan Penanggulangan Kemiskinan Berbasis Ketahanan Keluarga. IPB Press.

Puspitawati, H. \& Herawati, T. (2018). Reliabilitas dan validitas indikator ketahanan keluarga di Indonesia. Kependudukan Indonesia, 13(1), 1-14. https://doi. org/10.14203/jki.v13i1.283.

Puspitawati, H., Simanjuntak, M., \& Hayati, L. (2012). Kontribusi ekonomi dan peran ganda perempuan serta pengaruhnya terhadap kesejahteraan subjektif. Jurnal Ilmu Keluarga dan Konsumen, 5(1), 11-18. https://doi.org/10.24156/jikk.2012.5.1.11.

Robinson, K. \& Bessell, S. (2002). Woman in Indonesia: Gender Equity and Development. Institute of Southeast Asian Studies.
Saefullah, L., Giyarsih, S. R., \& Setiyawati, D. (2018). Pengaruh dukungan sosial terhadap ketahanan keluarga Tenaga Kerja Indonesia. Jurnal Sosiologi Pendidikan Humanis, 3(2), 119-132. http://dx.doi. org/10.17977/um021v3i2p119-132.

Serafini, G., Parmigiani, B., Amerio, A., Aguglia, A., Sher, L., \& Amore, M. (2020). The psychological impact of COVID-19 on the mental health in the general population. QJM: An International Journal of Medicine, 113(8), 529-535. https://doi.org/10.1093/ qjmed/hcaa201.

Suprayogaswara, D. (2017). Analisis faktor-faktor yang mempengaruhi produktivitas tenaga kerja Go-Jek di Kota Malang. Jurnal Ilmiah Mahasiswa Universitas Brawijaya, 6(1), 1-12. https://jimfeb.ub.ac.id/index. $\mathrm{php} / \mathrm{jimfeb} /$ article/view/4400/0.

Transmission of SARS-CoV-2: Implications for infection prevention precautions. (2020, July 09). World Health Organization (WHO). https://www.who.int/ publications/i/item/modes-of-transmission-of-viruscausing-covid-19-implications-for-ipc-precautionrecommendations

Valentino, M., Vionita, L., Utami, S. R., Ramadhani, S. N., Ramadhani, S. N., \& Qatrunnada, R. D. (2020). Webinar "Santap Sehat ala Rumahan di Era Pandemi COVID-19" di RT 02 Kelurahan Pulo Gebang Kecamatan Cakung Provinsi DKI Jakarta. Jurnal Layanan Masyarakat, 4(2), 456-464. http://dx.doi. org/10.20473/jlm.v4i2.2020.456-464.

Wahidin. (2019). Peran orang tua dalam menumbuhkan motivasi belajar pada anak Sekolah Dasar. Jurnal PANCAR (Pendidik Anak Cerdas dan Pintar), 3(1), 232-245.

Winurini, S. (2020). Bencana COVID-19: Stresor bagi pasangan suami istri di Indonesia. Aspirasi: Jurnal Masalah-Masalah Sosial, 11(2), 185-198. https:// doi.org/10.46807/aspirasi.v11i2.1755

Zahrok, S. \& Suarmini, N. W. (2018). Peran perempuan dalam keluarga. IPTEK Journal of Proceedings Series, 5, 61-65. http://dx.doi.org/10.12962/ j23546026.y2018i5.4422. 